\title{
The Effect of Heavy Metals Transport from Contaminated Soil to "Opuntia Vulgaris Mill" with the Use of Biologics
}

\author{
Alizade Alibala Mamedsadig Oglu, Zamanova Azada Pasha Gizi \\ Institute of Soil Science and Agrochemistry, National Academy of Sciences, Azerbaijan, Baku
}

Email address:

elielizada1943@mail.ru (A. A. M. Oglu), zamanovaazada@mail.ru (Z. A. P. Gizi)

\section{To cite this article:}

Alizade Alibala Mamedsadig Oglu, Zamanova Azada Pasha Gizi. The effect of Heavy Metals Transport from Contaminated Soil to "Opuntia Vulgaris Mill" with the Use of Biologics. American Journal of BioScience. Vol. 6, No. 1, 2018, pp. 1-5. doi: 10.11648/j.ajbio.20180601.11

Received: December 5, 2017; Accepted: December 15, 2017; Published: February 3, 2018

\begin{abstract}
Cleansing technogenically contaminated soils with the help of special plants is a more cost-effective and environmentally friendly method. When applying this technique, a special place is occupied by a decrease in the concentration of heavy metals, especially the concentration of its mobile forms in technogenically contaminated soil. In this case, a certain proportion of heavy metals and their mobile forms pass (transported) from the soil to the plant and the soil becomes less safe in an ecological sense, which is very important for its practical use. To enhance the effect of biological purification of the soil environment, it is very important to simultaneously enhance the accumulation effect in the soil itself of heavy metals using biological preparations. The purpose of this work was to identify the effect of accumulation in the soil using the plant as an indicator. The studies were carried out in the industrial zone of the Kala Absheron peninsula of Azerbaijan with the use of the plant "Opuntia Vulqaris Mill" under the conditions of biological activation of technogeneously polluted soil with the use of the "Biomax" preparation moved with treated organic fertilizer. The concentration of heavy metals was measured using a XRF Xray fluorescence spectrometer. The analysis of the obtained data showed that the biological activation of technogenically polluted soil medium even in an insignificant level (the level of biological activation was only $1.36 \%$ ) increased the effect of accumulation of 1.34 times heavy metals from the soil due to the effect of transport of these metals from soil to plant. Research of this effect is very important when using technogenically contaminated soils, under cultivated plants, which is not food.
\end{abstract}

Keywords: The Effect of Transport, Heavy Metals, Technogeneously Polluted Soil, Biological Activation,

Organic Fertilizers, Biological Indicator, Accumulation of Heavy Metals

\section{Introduction}

The plant "Opuntia Vulgaris Mill" from the family of cacti is adapted to save the consumption of moisture and retaining its maximum volume as a reserve. Each organ of this plant contributes to saving the consumption of moisture. The role of the root and stem of the plant "Opuntia Vulgaris Mill" boils down to the following. The system of lateral roots develops and is located at a depth of 5-6 cm from the soil surface. Therefore, even minor rains that barely moisten the earth are caught by the roots. The stem of this plant is juicy, green, leafless, covered with spines, hairs or both at the same time. In the prickly pear, the juicy subulate leaves appear in spring on the top of the shoot for a very short time, then wither and fall off. Opuntia, like any plant, grows its apex, called a growth point or apex. Due to the division of the cells of the growth point and their further growth, the prickly pear is increased in thickness and height. At the point of growth, the rudiments of leaves are laid in the form of small tubercles. If most plants develop normal leaves - with a petiole and a leaf plate, then the prickly pear is different. Anatomical studies have shown that the upper part of the leaf (or plate of the leaf) does not develop, but the division and growth of the cells of the leaf base, ie, in a zone where the tissue, the base of the leaf and the stem tissue closely adjoin, are at an enormous rate. Strongly expanding, these cells protrude on the stems of the prickly pear in the form of ribs and papillae. Where there are leaves (albeit very altered), the leaf foothills have the appearance of peculiar flat tubercles. The absence of leaves or their underdevelopment is the 
adaptation of the prickly pear to the harsh dry conditions of the habitat and, thanks to this, the plant less evaporates water.

The tissue of succulent plants is very homogeneous and is mainly specialized as a water-preserving plant. It consists predominantly of thin-walled cells. Cellular juice, along with organic acids and sugars, contains mucous substances that possess water retention properties. It is these biological features that allow the plant "Opuntia Vulgaris Mill" to accumulate and retain heavy metals through its moist environment in its vegetative organs and in some sense neutralize them [1], [2]. It is the biological and morphological features of this plant described above that allows it to play a role as a biological indicator in the process of phytoremediation of toxic metals [3], [4], [5], [6], [7], [8].

\section{Method}

\subsection{Selection of the Experimental Site}

To carry out a study on the transport of heavy metals from the soil to the plant "Opuntia Vulgaris Mill", a technologically polluted zone in the Absheron peninsula of Azerbaijan was chosen. By the method of random selection on a relatively flat spot, the locations of the experimental section with dimensions of $15 \mathrm{~m} \times 15 \mathrm{~m}=225 \mathrm{~m}^{2}$ are determined. The surface of the experimental site was cleared of foreign objects and from random plants. By random selection in three places in this section, soil samples were taken to determine the initial concentration of heavy metals [control variant]. Samples were taken on the soil surface at a depth of 10 centimeters. Six soil samples were taken from this site for analysis. The concentration of heavy metals in the soil was determined by the "XRF" X-ray fluorescence spectrometer [7], [8], [9].

The measurement results are shown in Table 1.

Table 1. Concentration of heavy metals in soil.

\begin{tabular}{llll}
\hline Heavy & \multicolumn{3}{l}{ Concentration $(\mathbf{m g}$ / kg) } \\
\cline { 2 - 4 } metals & Sample №1 & Sample № 2 & Sample №3 \\
\hline $\mathrm{Cd}$ & 2.16 & 2.06 & 2.21 \\
$\mathrm{~Pb}$ & 9.69 & 9.72 & 9.61 \\
$\mathrm{Zn}$ & 61.34 & 62.46 & 62,96 \\
$\mathrm{Ni}$ & 30.83 & 31.24 & 30.92 \\
$\mathrm{Co}$ & 4.78 & 4.62 & 4.71 \\
$\mathrm{Mn}$ & 41.35 & 41.78 & 40.29 \\
\hline
\end{tabular}

*) for each point, the concentration of heavy metals on the soil surface and at a depth of $10 \mathrm{~cm}$ was averaged.

\subsection{Soil Treatment with Organic Substrate}

After the soil samples were taken for analysis, the upper part of the experimental area was evenly moved at a depth of 5-10 centimeters with a dried organic fertilizer treated with $1.0 \%$ Biomax. The amount of organic fertilizer is calculated with the calculation of 10 tons per hectare $(10,000 \mathrm{~kg} /$ $10,000 \mathrm{~m}^{2}=1 \mathrm{~kg} / \mathrm{m}^{2}, 225 \mathrm{~m}^{2} \times 1 \mathrm{~kg} / \mathrm{m}^{2}=225 \mathrm{~kg}$ ). The quantity of the preparation of $1 \%$ "Biomax" a is determined with the calculation of 400 liters per hectare. (400 liters /
$10,000 \mathrm{~m}^{2}=0.04$ liters $/ \mathrm{m}^{2}, 225 \mathrm{~m}^{2} \times 0.04$ liters $/ \mathrm{m}^{2}=9.0$ liters). The average depth of the treated, biologically activated upper layer of man-caused contaminated soil in the selected experimental area averaged 7.5 centimeters.

\subsection{Determination of the Level of Biological Activation}

The level of biological activation of the selected medium (the treated top layer of the technogenically contaminated site) is determined as follows. The soil weight of the biologically activated layer with a thickness of 7.5 centimeters was

$$
\mathrm{m}=\mathrm{V} \rho=\left(225 \mathrm{~m}^{2} \times 0,075 \mathrm{~m}\right) \times 1000 \kappa \Gamma / \mathrm{M}^{3}=16875 \kappa \Gamma
$$

The weight of the active substance (dried organic fertilizer treated with $1.0 \%$ Biomax) was

$$
\begin{aligned}
\mathrm{m}^{*}=225 \text { кг }+\mathrm{V}_{1} \rho_{1} & =225 \text { кг }+9 \text { литров х } 0,9 \text { кг/литр }= \\
& =225 \text { кг }+8,1 \text { кг }=233,1 \text { кг }
\end{aligned}
$$

Then the biological activation of the treated layer in the ratio will be equal to

$$
\mathrm{K}=\frac{\mathrm{m}^{*}}{\mathrm{~m}} \cdot 100 \%=\frac{233,1 \kappa \Gamma}{(16875 \kappa \Gamma+233,1 \kappa \Gamma)} \cdot 100 \%=1,36 \%
$$

\section{Where}

m - soil mass;

$m$ * _ $\quad$ weight biologically active substance;

$\mathrm{V}$ - $\quad$ the volume of the soil;

V1- volume of $1.0 \%$ strength «Biomax»a;

$\rho$ - $\quad$ soil density;

$\rho 1$ - density of the solution;

K - biological activity coefficient

\subsection{The Drug “BioMax” Is Part of the Organic Substrate}

It should be noted that the liquid, concentrated biological preparation "Biomax" is a complex of organic and mineral compounds possessing high biological activity. The basis of the preparation is extract from biohumus. Additionally, microorganisms introduced into the extract and their metabolites increase the effectiveness of the action of bioorganic preparations on plants and on soil. The biological activity of these complexes depends on the ratio of metal ions, humic acids, natural phytohormones, enzymes and growth substances in them. Humic acids and chelates of microelements included in the preparation "Biomax", which is a natural stimulant of growth, affects the resistance of plants to low temperatures (frosts) and drought.

\subsection{Technique for Planting the Plant "Opuntia Vulgaris Mill”}

In the next stage of the experiment, the plant "Opuntia Vulgaris Mill" was transferred from an ecologically clean area to the prepared plot. The density of plant standing was selected in the same way in the same manner as in the 
experiment described in [7]. It should be noted that the dependence of the effect of heavy metals transport on the standstill of Opuntia Vulgaris Mill plants will be investigated later [10], [11], [12]. Observation continued for 6 months. At the end of the planned period, a random method was chosen from three sites in the experimental plot, together with the root system, 3 plants were selected: "Opuntia Vulgaris Mill". Each plant separately, after washing the root system was dried. After using special technology 3, the samples of the plant under investigation were prepared for measurement.

\subsection{Determination of the Concentration of Heavy Metals in Plants “Opuntia Vulgaris Mill”}

The concentration of heavy metals in plant samples is determined using an "XRF" spectrometer. The results of measurements are shown in Table 2.

Table 2. The concentration of heavy metals in plants samples «Opuntia Vulgaris Mill» after the experiment.

\begin{tabular}{llll}
\hline \multirow{2}{*}{ Heavy metals } & Concentration (mg / kg) & Sample №3 \\
\cline { 2 - 4 } & Sample №1 & Sample № 2 & 1.44 \\
$\mathrm{Cd}$ & 1.38 & 1.31 & 4.36 \\
$\mathrm{~Pb}$ & 4.29 & 4.17 & 35.26 \\
$\mathrm{Zn}$ & 34.56 & 32.19 & 17.09 \\
$\mathrm{Ni}$ & 16.42 & 15.92 & 1.98 \\
$\mathrm{Co}$ & 1.92 & 1.84 & 12.47 \\
$\mathrm{Mn}$ & 12.25 & 11.93 & 12 \\
\hline
\end{tabular}

\section{Result}

Averaging in Table 1 gave the following results on the concentration of these heavy metals in technogeneously polluted soil (in Edinets $\mathrm{mg} / \mathrm{kg}$ ):

$\mathrm{Cd}=2.14 ; \mathrm{Pb}=9.67 ; \mathrm{Zn}=62.25 ; \mathrm{Ni}-31.01 ; \mathrm{Co}, 4.70 ;$ $\mathrm{Mn}=41.14$;

Averaging from Table 2 gave the following results on the concentration of these heavy metals in the samples of plants "Opuntia Vulgaris Mill" (plant samples are homogenized by the vegetative organ and the root system together):

$\mathrm{Cd}=1.39 ; \mathrm{Pb}=4.27 ; \mathrm{Zn}=34.01 ; \mathrm{Ni}=16.48 ; \mathrm{Co}-1.91$; $\mathrm{Mn}=12.22$.
It should be noted that, in specific soil and in specific climatic conditions of the region and in the presence of a certain type of plant, the properties of the soil can significantly affect the accumulation of heavy metals in plants. Heavy metals are the most mobile in low-humus soils, acidic, light granulometric composition with low cation exchange capacity and low buffer capacity. The soil shows its buffer properties, by converting metal compounds, soluble in water to a moderately soluble form and hardly soluble for more mobile. Nevertheless, the buffer capacity of the soil is not unlimited and the amount of such compounds in which they enter the soil, and then gradually grows to the plant with an increase in the concentration of the exogenous metal.

Table 3. Concentration of heavy metals in comparative form.

\begin{tabular}{lllll}
\hline \multirow{2}{*}{$\begin{array}{l}\text { Heavy } \\
\text { metals }\end{array}$} & \multicolumn{2}{l}{$\begin{array}{l}\text { Concentrations of heavy metals in } \\
\text { tehnogenno contaminated soil }(\mathbf{m g} / \mathbf{~ k g})\end{array}$} & The concentration of heavy metals in plants samples «Opuntia Vulgaris Mill» (mg / kg) \\
\cline { 2 - 5 } & {$[7]$} & present work & Without biological soil activator [7] & $\begin{array}{l}\text { From a biological activator of the soil (Biomax) } \\
\text { (This work) }\end{array}$ \\
\hline $\mathrm{Cd}$ & 2.27 & 2.14 & 1.86 & 1.39 \\
$\mathrm{~Pb}$ & 9.58 & 9.67 & 5.59 & 4.27 \\
$\mathrm{Zn}$ & 60.28 & 62.25 & 46.40 & 34.01 \\
$\mathrm{Ni}$ & 31.76 & 31,01 & 22.32 & 16.48 \\
$\mathrm{Co}$ & 4.60 & 4.70 & 2.46 & 1.91 \\
$\mathrm{Mn}$ & 39.76 & 41.14 & 16.57 & 12.22 \\
\hline
\end{tabular}

On the other hand, in [7], the results of transport of heavy metals from technogenically contaminated soil to the plant "Opuntia Vulgaris Mill" were obtained without the use of a biological activator. It is pertinent to note that the conditions of the experiment, which was realized in [7], are almost very close to the conditions of technogenic contamination described in this work, that is, both experiments were conducted at different times in the technologically polluted zone of the Kala Absheron peninsula of Azerbaijan. Table 3 shows in a comparative form the results of both experiments.

\section{Discussion}

Systematization of the data from [7] and from the present work made it possible in comparative order to evaluate the effect of heavy metals transport from technologically polluted soil to the plant "Opuntia Vulgaris Mill" for both cases: without using a biological preparation for soil and using a biological preparation for soil. The results of the comparative analysis are shown in Figure 1. 


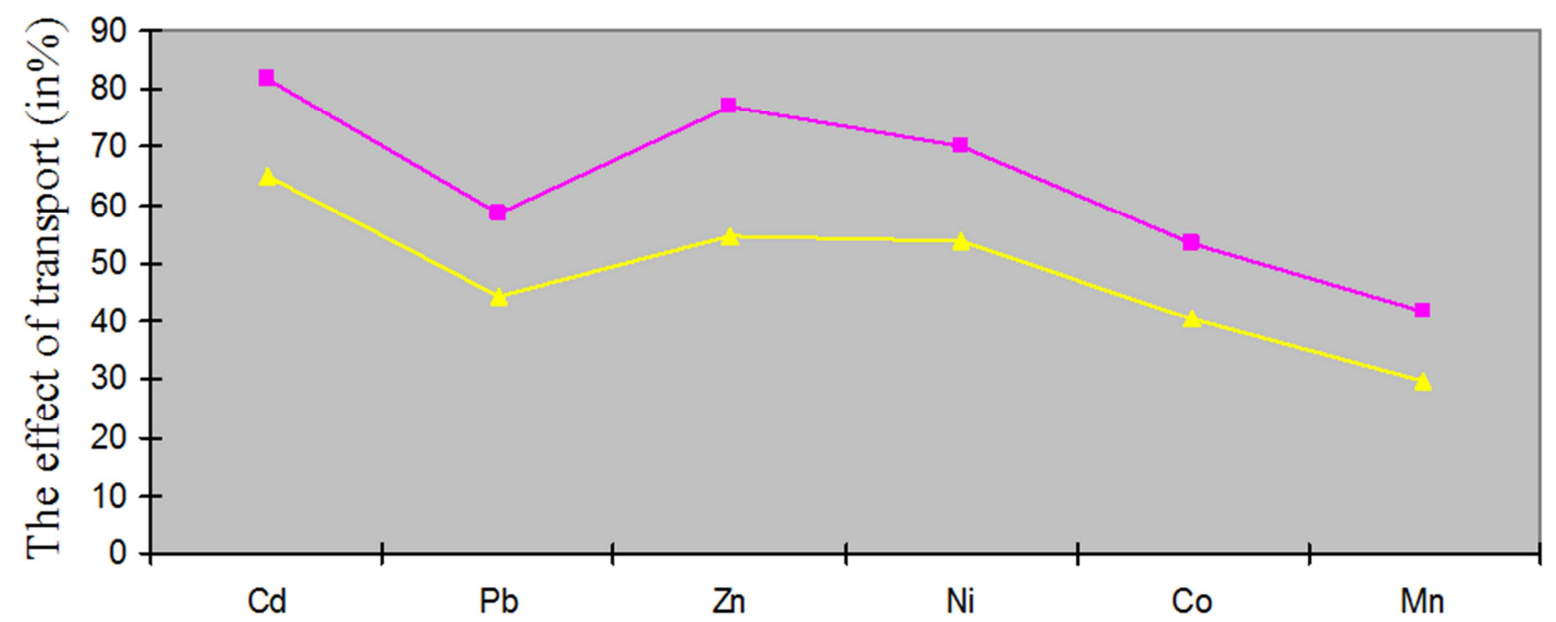

Figure 1. The effect of transport of heavy metals from technogeneously contaminated soil to the plant Opuntia Vulgaris Mill." Upper curve- The effect of tansport without the use of biopreparation; Low curve - The effect of transport using biopreparation.

The effect of transport (TE) of heavy metals from technogeneously contaminated soil to the plant "Opuntia Vulgaris Mill" in percentages is calculated as follows.

$$
\mathrm{TE}=\frac{\mathrm{CON}(\mathrm{HM})_{\text {plant }}}{\mathrm{CON}(\mathrm{HM})_{\text {soil }}} \cdot 100 \%
$$

Where

$$
\begin{array}{ll}
\text { TE - } & \begin{array}{l}
\text { The effect of transport selected heavy } \\
\text { metals; }
\end{array} \\
\text { CON (HM) plant - } & \begin{array}{l}
\text { The concentration of heavy metal in } \\
\text { the selected plant; }
\end{array} \\
\text { CON (HM) soil - } \quad \begin{array}{l}
\text { Concentration of selected heavy } \\
\text { metals in soil. }
\end{array}
\end{array}
$$

\section{Conclusion}

An analysis of the data presented in Figure 1 shows that, with the application of a biological preparation for soil, the effect of heavy metal transport slows down, on average, 1.34 times on the effect of transport without using a biological preparation for soil. This effect can be explained as follows.

The biological activation of technogenically polluted soil medium, although biological activation in the homogeneous approximation was only $1.36 \%$, generated at the molecular level or otherwise said increased concentrations of $\mathrm{OH}$ bonds, which plays an important role in the process of accumulation of heavy metals in the soil environment. The reduction in the effect of heavy metals transport from technologically polluted soil to the plant "Opuntia Vulgaris Mill" is associated with an increase in the accumulation of heavy metals in a biologically activated soil environment. Except as a scientific result, the effect of transporting heavy metals from the soil to the plant due to the increase in the effect of accumulation of heavy metals in the soil itself is very relevant when using technogenically contaminated soils under cultivated plants that are not food products.

\section{Acknowledgements}

This work has been executed in Institute of Soil Science and Agrochemistry of the National Academy of Sciences of Azerbaijan and was supported by the Science Development Foundation under the President of the Republic of AzerbaijanGrant No. EIF-KETPL-2-2015-1(25)-56/38/3-M-38.

\section{References}

[1] Weniger D. Casti of the south-west-Austin et. London University, Texas press, 1988.

[2] L. Milner. Carbon and water relations for developing fruits of Opuntia ficus-indica (L.) Miller, including effects of drought and gibberellic acid. Journal of Experimental Botany. 55(397) pp.719-729, 2004.

[3] Lasat MM. Phytoextraction of toxic metals: a review of biological mechanisms. J Environ Qual. 2002 Jan-Feb; 31(1): 109-20. U.S. Environmental Protection Agency, Office of Research and Development, National Center for Environmental Research, Washington. DC 20460, USA.

[4] Nascimento CWA, Xing B, Phytoextraction: A review on enhanced metal availability and plant accumulation. Sci, Agric. (Piracicaba, Braz) 2006; 63(3), 299-311.

[5] Vinita H, Phytoremediation of toxic metals from soil and waste water. Journal of Environmental Biology, April 2007, 28(2) $367-376$.

[6] Elizabeth A. H., Pilon-Smits E, John L. Environmental cleanup using plants: biotechnological advances and ecological considerations. Front Ecol Environ 2006; 4(4): 203-210.

[7] A. P. Zamanova, T. S. Mamedov, Z. H. Abbasova, C. T. Namazova and M. Y. Hasanova, Research of transport effects of heavy metals in plants of Opuntia Vulgaris Mill grown in the technogenic contaminated soils, Global Journal of Biology, Agriculture and Health Sciences, October-december, 2015, Vol. 4(4); 7-9. 
[8] Azada Zamanova, Treatment of Contaminated Areas through Opuntia vulgaris Mill, The 3rd International Symposium on Eurasian Biodiversity- SEAB, 2017.

[9] Kirpichtchikova, T. A., Manceau, A., Spadini, L., Panfili, F., Marcus, M. A. and Jacquet, T. (2006) Speciation and Solubility of Heavy Metals in Contaminated Soil Using XRay Microfluorescence, EXAFS Spectroscopy, Chemical Extraction, and Thermodynamic Modeling. Geochimica et Cosmochimica Acta, 70, 2163-2190.

[10] Orudzheva, M., Babayev, P., Isgandarov, S. M. and Alizade,
A. (2013) Influence of the Plant Density on Productivity. SoilWater Journal, 2, 1021-1028.

[11] Orudzheva, N. İ., Babayev, M. P. and Isgandarov, S. M. (2014) Dependence of the Plant Productivity on Optimal Food Regime and Density. American Journal of Plant Sciences, 5, 436-441. https://doi.org/10.4236/ajps.2014.54057.

[12] Alizade A., Zamanov P., Zamanova A. and Isgenderov S. (2017) Dependence of the Yield of Alfalfa on Plant Density and Diet. American Journal of Plant Sciences 8, 2722-2731. https://doi.org/10.4236/ajps.2017.811183. 